\title{
Euthanasia and the Concept of Safeguarding Life a Literature Review
}

\author{
Dr. Ahmad Bin Muhammad Husni ${ }^{1 *}$, Nur Fatin Alimuddin² \& Dr. Wafaa Yusof ${ }^{3}$ \\ ${ }^{1}$ Lecturer at Department of Fiqh \& usul al-Fiqh, Kulliyyah of Islamic Revealed Knowledge \& Human Sciences, (KIRKHS), IIUM Gombak Campus, \\ P.O. Box 10, 50728 Kuala Lumpur, International Islamic University Malaysia \\ ${ }^{2}$ MA Student, Jabatan Syariah, Fakulti Pengajian Islam, Universiti Kebangsaan Malaysia, UKM, 43600 Bangi, Selangor, Malaysia \\ ${ }^{3}$ Jabatan Syariah, Fakulti Pengajian Islam, Universiti Kebangsaan Malaysia, 43600 UKM Bangi, Selangor, Malaysia
}

DOI: 1 10.36348/sjhss.2019.v04i11.009 $\quad$ | Received: 20.11.2019 | Accepted: 27.11 .2019 | Published: 30.112019

*Corresponding author: Ahmad Bin Muhammad Husni

\section{Abstract}

Euthanasia is one of the very significant bioethical issue that has been widely developed in a complex way line with the medical advancement, biotechnology, intensive care unit as well as the medical technology. The essential of science and technology in medical today towards human cannot be denied which not only help in treatment to cure any disease but also able to identify any illness effectively and accurately through diagnosis. However, what raises the question is when euthanasia is considered as an easy, silent and less painful way to terminate the pain that has been borne by the incurable patients. The compassion and the right to die is one of the strong excuses to enable euthanasia to be practiced by the Western. Hence, the objective of this research is to explain the concept of euthanasia practice and the Islamic approach towards the purity of life. This is a qualitative study that uses the document analysis. The finding from the study shows that there are differences in the practice of euthanasia from the Western and Islamic perception. Islam believes that euthanasia opposed the concept of natural death and against the human nature.

Keywords: Euthanasia, Western, approach, Islam, life.

Copyright @ 2019: This is an open-access article distributed under the terms of the Creative Commons Attribution license which permits unrestricted use, distribution, and reproduction in any medium for non-commercial use (NonCommercial, or CC-BY-NC) provided the original author and source are credited.

\section{INTRODUCTION}

Life is a precious gift from Allah to human being. According to Islam, all mankind that live in this world has their main purpose. First and foremost, they live to serve Allah as well as to become the khalifah on the earth. In order to achieve the second purpose in their life, human is commanded by Allah to have faith and obey Him solely. After they taste life, human shall face death that has been determined by Allah. This can be clearly seen in surah Ali Imran verse 145 which Allah says: And it is not [possible] for one to die except by permission of Allah at a decree determined. Hence, it can be understood here that according to Islam, the life and death concept is the absolute provisions of Allah.

Meanwhile, euthanasia which also known as the mercy killing is the Western ideology that makes it as a right to ends someone's life [1]. This problem always becomes a pressure in bioethical world. The technology advancement in medical field has brings this issue to the core to be deeply studied. In relation to that, euthanasia needs to be clearly understood in order to consider its position in terms of law, ethics and religion perception [2]. The history background proves that euthanasia is the Western ideology that comes from the
Greek word that means mercy killing taken from Greek word, "euthanatos" which means "good death". Euthanasia actually is not a new issue which in fact it has even exist since the ancient Greek time. The history of the early opposition towards euthanasia begins with the oath from the medical practitioners of Greek, Hippocrates is the father of medical. Hippocratic oath says that: "I will not prescribe a deadlydrug to please someone, nor give advice that may cause his death" [3]. Since then, medical ethics have existed in the last 1400 years before BC [4]. Medical etiquette is used as the basis for regulating the medical system and as a guide that binds the behaviour of nurses and patients during and after undergoing treatment sessions.

This clearly shows that the euthanasia is against the theory and practical medicine and raising questions about the attitude and ethics of humanity in modern social life and religious perception of its implementation [5]. Euthanasia, is it the ending of life by killing or being murdered? This question also poses a controversy that needs to be studied in terms of human nature. Generally, the birth and death event are the fate and under the power of the God. Likewise, it is 
the weakness of a human who cannot avoid or determine death. According to chronology there are three types of death processes namely Orthothanasia (normal or natural manner of death), Dysthanasia (bad death) and Euthanasia (death with the assistance of other parties including medical personnel).

Hence, this research is to study the concept of euthanasia practice according to the Western and the approach of Islam in the purity of human's life. This study focuses on the concept of euthanasia and its explanation according to medical organizations, legal and Islamic scientists through the theory of al-Qur'an and al-Sunnah.

\section{RESEARCH METHODOLOGY}

According to this research methodology, researcher laying out a framework based on things related to the designs of data collection and data analyser. It aims to publish a quality finding through the previous studies on the concept of euthanasia practice and Islamic approach towards the purity of life. This study uses qualitative research designs to address issues, themes and theories as the main focus.

Based on this research, the researcher collects the data through the analysis of medical books, author of the fuqaha books, journals, articles and the working papers of the proceedings relating to this study. Content analysis refers to an objective and systematic explanation of the information obtained. The researcher analyzes the data collected using descriptive and deductive methods to identify the concepts in this study referring to each reference document. The researcher then explores and elaborate the concepts that have been identified in detail.

\section{LITERATURE ANALYSIS}

The issues presented in this study point to the question of the concept of euthanasia practice according to Western perceptions and Islamic approach to the purity of human life. To get the results of the study, the author analysed some of the earlier studies on this topic and divided the literature review into two major issues and made it four subtopics to answer the research questions

\section{THE CONCEPT OF EUTHANASIA PRACTICE ACCORDING TO THE WESTERN POINT OF VIEW}

Euthanasia is one of the ideas that have been introduced by the Western as an easy way to terminate a very sick person's life in order to relieve them of their suffering which has an incurable condition. According to the Western perception, the quality of life is very pertinent and the illness of someone will only give burdens to their family to bare their treatment cost.
Understanding; The Etymology and the Reason of practicing Euthanasia

First, the euthanasia concept is reviewed through etymology, Robert M. Baird [6] stated that Greek words $e u$, well, thanatos referring to death in a good and easy way. In the Mosby's Medical Dictionary [7] the connotation of 'mercy killing' is synonym with euthanasia etymology and is a professional vocabulary that is often used in medical scientific terms. It refers to acts that cause death slowly on individuals suffering from illnesses that is incurable.

It can be in an active situation such as taking drugs or in passive way by stopping the treatment. Meanwhile, euthanasia is also defined as the goal of ending one's life to end the physical suffering by Euthanasia Society of America 1938.

Other than that, euthanasia has been debated by contemporary scholars as a new problem that exists in the debate from the context of Islamic jurisprudence. Euthanasia was mentioned as qatlu al-rahmah (mercy killing). Al-Qaradhawi [8] explains that euthanasia is the process speeding up death of a person without misery on the basis of sympathy to alleviate the suffering either done directly or vice versa. Hirbah Salim [9] on his opinion stated qatlu al-rahmah not only the death of peace, but also the honorable way of depriving one's life without feeling ill at death either on the request of the patient himself or with the help of others to calmly turn ends his life.

Referring to historical sources, Euthanasia is one of the violations of the principles of medical ethics that has been heavily influenced by British colonization. Omur Elcioglu's research [10] explaining the statement by Thomes More in the 16th century, the United States advised the patient suffers from an illness that cannot be cured and suffers from the illness to agree to disable himself or shut himself up. This is because, the patient should be aware that the illness is incurable and it will be a burden to others, especially the family members who are forced to bear the cost of treatment and suffering will cause others to feel sorry for them. Meanwhile, Philip Gavin's study [11] mentioned Adolf Hitler's words "Those who are found to have chronic illness that can not be cured after undergoing diseaselevel diagnosis should be exercised non-voluntary euthanasia on them or synonymous with the term killing mercy". These ideas show a marked betrayal on the real medical code of ethics and lead to moral and religious discrepancies as well as violate human rights ethics for life while most religions believe that only a powerful god takes on human life [5].

The American Medical Association's Council on Ethical and Judicial Affairs [12] mengklasifikasikan eutahanasia lassifies eutahanasia as a lethal action for patients suffering from illness and losing hope through a fast way on the basis of compassion. The study on the 
official websites (http://www.euthanasia.com) [4]. The application process of euthanasia is divided into two parts which are active and passive euthanasia and can be further divided into three situation namely voluntary (occurs at the request of the person who dies.), involuntary (without the patient's consent) and nonvoluntary (the explicit consent of the individual concerned is unavailable). Through the same resources, there are five strong divisions that make it the basis of the truth of carrying out euthanasia procedures in the legal system, practical medical and general policy namely the factors of Compassionate, Autonomy (freedom), Right to commit suicide, Quality of life and Economics.

\section{Justification of Euthanasia in Western Legislation}

Western scholarship expertise has created a theory of rights known as human rights. Human Rights Movement was built to fight human rights issues through the diversity of theories. Hence, the justificatio for euthanasia in the concept of human rights has also been studied. Looking closely to the matter, there is a shortage of practicalities in which many violations of human rights are especially in Islamic countries [13]. Euthanasia proves the true value of the human rights violation because it is one of the issues that deals with the right to life. According to Abdullah [14] murdersuppression is not a weird thing. It has happened since the Greek civilization when a woman giving birth to a child in unusual way they will be killed. This is because, The evolving human rights movement in the West are based on liberalism and humanism [15].

According to Syed Muhammad Naquib alAttas [16], humanism is based only on the basis of humanity and worldliness as well as materialism without considering the religion, or teachings and beliefs of the divine. The concept of human rights brought by Western countries separates people from God (devided God) as well as religion and laying human rights as an absolute right acquired naturally from birth. The element of secularism also explores human rights which separates the affairs of the world and religion in full adherence to the human mind patterns. Dr. Brian Pollard [17] in his research explains that euthanasia practise was appointed as an individual's right and freedom of choice to die based on 'freedom and liberty' whereas it contravenes the Universal Declaration of Human Rights in 1948 which declares the principle of freedom in the world is justice and security.

In addition, the euthanasia position in the Dutch and Belgian legislative structures is the earliest country that recognizes euthanasia through codification code including in medical and practical procedures of doctoral. Based on the writing of Professor Robert Pearlman [18] in the book entitled Physician-Assisted Dying: The Case for Palliative Care and Patient Choice, among the popular factors that has been used by chronic cases, the patients used to ask for euthanasia or physician assisted suicide to be done on them due to insufficient treatment requirements for treating illnesses or another symptom are depression, discontent, socioeconomic stress and economic hardship that is burdensome to family members to bear the cost of their treatment. The overview on Dutch Penal Code 1886 through section 293294 find that. The enactment distinguishes between taking the life that is contrary to one's right and taking on life on the basis of one's request. In short, Euthanasia, (refers to Article 293) and assisted suicide (refers to Article 294) is exempt from criminal offense. The court outlines the doctrine 'force majuere' as a theory to free the doctors from being charged of any offences with which it may be interpreted that the act of ending the illness of a patient is part of the doctoral assignment as well as having continuous support from the law to state that euthanasia is also a physician's duty referring to the Artikel 40 of Dutch Penal Code.

Meanwhile, Belgium has codified euthanasia legislation as an initiative to relieve patients from suffering pain while allowing drug use to shorten their lives and expedite patient death through Article 78 of Chapter (1): Section (2) of The Belgian Act Euthanasia of May, 28 $8^{\text {th }}$ 2002. According to the study of euthanasia case (1998), in Belgium the ending of the patient's life has become a practical practice among medical practitioners almost reaching the frequency of case records in the Netherlands Dr. Marc Moens (t.th) states that there are more than 40,000 protests by medical practitioners (Belgian Association of Doctors Syndicates (BVAS) against the elimination of euthanasia laws does not seem to result in any changes in preventing the abuse of such action. Belgium Senate (October 2001) has approved euthanasia in the draft of legislation on the exclusion of euthanasia from any criminal prosecution in the provision of Chapter (2) under the terms and procedures, Section (3) of The Belgian Act Euthanasia of May, 28th 2002 that the Doctor is allowed to end the lives of patients who have no hope of recovering from illness and miserable pain. The procedure can be administered to at least 18 years of age (the majority of the age limit for freedom) voluntareed, concious and often made a request to take his life. The request must be made in written document by placing date and patient's signature. Justin Sparks [19] explained that euthanasia in Belgium did not receive full approval from the Belgian Medical Association as in Netherlands. They are agreed that the provisions of the law on euthanasia open wide space to end one's life.

Regarding on the question of euthanasia recognition in the law, there are criticisms from researchers such as Otlowski [20] through his research Voluntary Euthanasia and the Common Law; legal aspects and euthanasia, the laws created do not reflect the practice, effective implementation and enforcement 
in the reality of relationship between doctors and patients in practical life ending. It shows that there is a discripancies between the theory and the implementation of the law as well as hypocrisy. According to the research on Euthanasia, Ethics and Public Policy; An Argument Against Legilslation by $\mathbf{J}$ keown [21], criticized the euthanasia legislation and its development in the Netherlands and Belgium. The objection on the voluntary assisted euthanasia and physician assisted suicide as it is something immoral. Brendan Greena [22] in Understanding Medical Law explains the basic medical law to touch on the aspect of human life thus causing the question of two conditions between one's life and death. The law's objective is to address the medical problems that arise as patients refuse to accept treatments and reactions to the increased number of claims on negligence in medical field. These things have triggered a dilemma between ethics and law.

These studies prove that euthanasia creates a conflict not only among the people but also the system of law provisions that conflict with the theory of the real struggle of the individual's rights of life. There is a question here when there is a declaration aimed at protecting universal rights but in the same situation there is a recognition of action that suppresses and threatens the right to freedom of living while medical necessities are also included in the human needs category.

\section{ISLAMIC APPROACH TOWARDS THE PURITY OF LIFE \\ Methodology of Islamic Creed}

The Islamic approach to purity of life refers to the nature of the human described in the Qur'an and the arguments proving that human life is the gift of Allah and His absolute right. Al-Asfahani [46] explains the word al-nafs that has been mentioned in al-Qur'an refers to two main points namely self referring to humans from the angle of lust, reason, body and spirit and life which resides or is placed in the body and body of the human body if it is separated from the body then the human being is said to have died. Allah said, (alFussilāt:41:53):

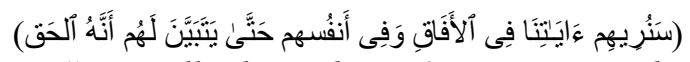
Meaning: "We will show them Our signs in the horizons and within themselves until it becomes clear to them that it is the truth".

According to mufassirin, al-Sabuni [23] the interpretation of this verse that Allah has explained to the Musyrikin that they should see the evidence and argument of the truth (rights) shown in the Qur'an as it is a book revealed by Allah S.W.T. Allah calls to see other creations such as the heavens and the earth and the miracle of Allah created man and nature. al-Qurtubi [24] said: "what is meant by the phrase في أنفسه that is the tenderness in creation to refer to the nature of God which contains all such wisdom as a man who eats and drinks somewhere, so he can remember and distinguish the place with other places. This analogy means one will remember where he came from.

The role of the Qur'an as a reference and guidance to human beings in reviewing the origin of human self-existence should be seen through the methodology of the creed. First, it refers to the concept of nature. The tafsir scholars explained that the meaning of nature is authentic and correct refers to the word of Allah in al-Rūm:30:30 which means: So direct your face toward the religion, inclining to truth. [Adhere to] the fitrah of Allah upon which He has created [all] people. No change should there be in the creation of Allah. That is the correct religion, but most of the people do not know [25]. The Fitrah of Allah which is meant in the proposition concerning human being created by Allah has religious instinct which is the tauhid religion is Islam. This is reinforced by the word of Rasulullah SAW:

$$
\text { "كل مولود يولا على الفطرة" }
$$

Meaning: That every born, is in a state of nature, (alBukhari, Sahih al-Bukhari, kitab al-Janaiz (the dead body): the children of Islam, bab ma qil fi aulād almusyrikin).

Second, it encompasses the process of human creation that have been revealed by God S.W.T in alMu'minun:23,12-16. Accroding to al-Alusi (t.th) [45], this verse is a signal to the original process of the human creation - the first human being created by God (Adam A.S). The Mufassirin also states that the process of creation of Adam A.S There are seven stages namely the last stage blown by God's spirit into the body and made it as the perfect creature [26].

Thirdly, the process of death is also stated in the Qur'an closely related to the methodology of a Muslim creed. Surely life and death are under Allah's will. There is nothing to be determined (qadar) by other beings except Allah alone. However, if He desires to restore the soul and soul of a sleeping person into his body, then he will continue his life. But if Allah wills otherwise then he is the spirit of the dead [27]. More definite if referring to the intended al-Qur'anic proposition which means: Every soul will taste death, (Surah Ali Imran:3, 185).

Furthermore, the disease and the test are conditions that limit the dimensions of human reason that are also closely related to the methodology of faith and the concept of faith with Allah SWT. Referring to the word of Allah S.W.T, (al-Qur'an, surah alBaqarah:2, 155) [28]

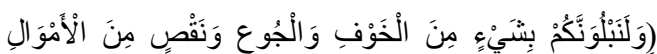

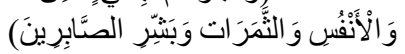


Meaning : And We will surely test you with something of fear and hunger and a loss of wealth and lives and fruits, but give good tidings to the patient.

According to al-Zuhaily [29], in the interpretation of this verse, Allah brings a favor sometimes with the test and various disasters. Yet there is no cure for the misfortune except by seeking the help of Allah SWT by patience. The tests sent down by Allah are likely to be in various forms such as the death of a loved one, loss of property or disease. Regardless of whether the disease occurs within a long or intermittent time frame depending on the (qada) of Allah. This has been justified in the hadith of the Prophet (peace be upon him) which means: "No Muslim is afflicted with a disease or other affliction except that his sins are removed from him as leaves fall of a tree [30]." In Islam this process is referred to as kiffarah hat is Allah's punishment in the world due to the sins committed by his servant or the purification of $\sin$.

Islam has placed care arrangements for sick people through the nature of responsibility and trust that family members should take in ensuring the patient's welfare is maintained through love and compassion. The resrach of Manzoor Malik [31] through Euthanasia: An Islamic Perspective states that if this is understood correctly then there will be no form of murder either from the patient or the family member. Psychological support is also very important as most cases of euthanasia occur due to the feelings of extreme pressure. Hence, any action involving life such as killing or destruction or putting self in a substance that can destroy self is prohibited in Islam.

\section{Life in Islam according to Islamic Protection Rights}

The intended Islamic protection rights refer to "al-Haqq" terminology Al-Kafawi [32], right to something that is obligatory and thabit (permanent). The right has a diversity of meanings that refer to the names of Allah Ta'ala or its attributes, Qur'an, against the falsehood, the command from the issuer of orders, fair, Islam, property, rights, the existence of conviction, permission, death, one of the responsibilities [33]. Meanwhile, according to al-Zuhaily [34], Rights are a constant benefit to individuals and communities or to both concurrently where it has been set by Allah the Almighty. Right is also something that is recognized through the Islamic Shariah foundation to a person that involves wealth, self and moral and social.

Life in the context of the rights owner touches from the right of (sohibul haq) means a person who has the right on something according to what has been set up includes the right of Allah (haqqullah) and human being (haqqul ibad). Allah is the sole owner of the right in the Islamic Law whether the right is related to religious, personal or legal affairs [34]. According to Ibnu Nujaym's [35] view (t.th) stating the main purpose of the law in Islamic law is to manage and determine the rights associated with individuals and communities. According to usuliyyun fuqaha', the right to include general and specific benefits can divided into four owners namely; The right of Allah solely, the right of the slave (man) to the fullest, the sharing of the two rights and Allah has the ultimate right as the as well as the sharing of two major rights and human beings has the main right on it.

Human beings have certain rights and one of them is the general rights which also knows as huquq al-insan. The right is recognized for every person regardless of status, religion, position in society and skin color. Granting rights is based on human nature as the people of the prophet Adam. . Hence, huquq alinsan (human rights) need to be recognized without any comparison of the offspring, skin color, and language spoken [36]. Accoridng to al-Zuhaily [37], Human rights are a collection of some natural human rights that are closely related to the existence of $\operatorname{tabi}^{c} i$ which is naturally certified. The main principle of human rights is based on principles al-karamah al-insaniyyah namely the honor and glory of human dignity. It was also emphasized by Al-Mawdudi [38] that every human being in a society and nation needs human rights in many important aspects such as the right to choose religion, the right to life, the right on self-respect and the family, the right to speak and to give a view and so on

There is discrimination in euthanasia that against the right of chronic patients. According to Audah [39] life and body are a gift from God that is important to be take care of. Islam prohibits any act that can cause death and injury to one's self or other person. In this case, Islam has provided a law under the qisas criminal offenses. Islam brings a paradigm shift in the context of human rights such as returning to the original nature of humanity and placing humans in the real position in line with the ultimate goal of man created by God. Abu Zahrah (t.th) [40] stated that whatever type of crime is a violation of society, or is referred to through the term Islamic law as a violation of the rights of Allah SWT. According to Al-Qaradawi [41] the scope of the preservation of rights brought by Islamic syariah not only guarantees the rights of individuals but also ensures the right of the community to work through the concept of balancing between the importance of keeping common and specific goals simultaneously.

Tyranny will cause the collapse of civilization, a country and its entire population. Therefore, the wisdom of Syariah and the purpose to prohibit the desruction and deterioration of human quality of life occurs through the preservation of five matters namely; religion, life, intellect, wealth and wealth [42]. Al-Yubi, Muhammad Sacad [43] also explained that the strengthening of the maqasid of sharia structure is with the principle of taking advantage of and rejecting the harm as mentioned by Ibn ${ }^{\mathrm{c}}$ Ashur [44] maslahah means 
the benefits of action that is in line with the requirements of Islam that are capable of achieving the ultimate goal of Shariah to provide the prosperity of human being in this world and the hereafter. Meanwhile, mafsadah refers to acts that contrary to the requirements of syarak which can lead to damage and harm as well as obstruction of sharia goals in ensuring the well-being of human life.

The explanations in the studies of the scholars show that Islam has a practical approach in preserving the sanctity of life that has been conferred by Allah SWT as it has been proven in the Qur'an and al-Sunnah. The concept of a faith held by every Muslim plays an important role not only in the aspect of worship but also in the psychological and intellectual approaches especially when it comes to any misfortune and trials such as chronic disease.

\section{RESEARCH FINDINGS AND DISCUSSION}

The literature overview of previous studies found that the concept of euthanasia has been designed by the West to eliminate the pain suffered by chronic patients is contrary to the concept of natural death of human (alamiyah).

\section{The Concept of Euthanasia Practice According to the West Legislation}

The concept of ending ones life through the application of euthanasia shows a significant contradiction with the practice of Islam through the context of humanitarian determination is a decree determined by Allah and only in His knowledge. All the clear prominence stated for the execution and demands of the euthanasia procedure is totally contrary to the reasons allowed by Islam on the life of a person based on the hadith of the Prophet: "It is not permissible to spill the blood of a Muslim except in three [instances]: the married person who commits adultery, a life for a life, and the one who forsakes his religion and separates from the community." (Riwayat Ibn Majah, Sunan Ibn Majah, kitab hudud, Chapter: prohibition of blood of a Muslim).

From the legal position, euthanasia recognition opens up a wider space for killing. The law is used as an initiative to release chronic patients from surviving in a state of having a great pain. However, the act of depriving lives through euthanasia is not considered to be a murderous crime when it exists within Dutch Penal Code; Article 294 ,euthanasia that go through physician assisted suicide exempted from the crime of murder and Article 40; Euthanasia is considered as part of a doctor's task. There was also a waiver of any criminal charges under the Belgian legislation.

\section{The Islamic Approach towards the Purity of Life}

Unlike the Islamic approach, the concept of illness or the test is related to the principle of faith and the foundation of the Islamic Faith which are to believe in Allah and to believe in qada' and qadar. Regarding to the protection of rights, Islam preserves the sanctity of life as

an invaluable gift of Allah SWT to be preserved by every human being. Hence, Islam puts the life invasion as a grave crime under qisas penalties or compensation ransom paid (diyah).

This is because the main objective of the maqasid of syariah is the basis of Islamic welfare and justice which does not allow any violation of human rights, including the life which is absolutely belongs to Allah.

As such, through this literature review, the authors can identify the differences and analyze the comparisons between the concepts of euthanasia practice in the scope of understanding and implementation of the West as well as the rejection of Islam on this practice through an effective approach of the al-Qur'an and al-Sunnah method to deal with euthanasia problems.

\section{CONCLUSION}

Logically, the entire Western country rejects and does not accept any form of cruelty and homicide. However, euthanasia is considered as 'mercy' on the basis of sympathy for someone who is suffering from chronic illness to bear life in pain. The policy has made euthanasia practical as medicine and its factors are framed in law as well as influenced by other factors such as political agendas. However, the objective of safeguarding Islamic welfare does not justify the action of taking other human lives on the basis of compassion and sympathy. The justification of syarak has proved that the human life is the absolute right of Allah. Human intervention on the life of a person will result in the Islamic criminal procedure being carried out covering two main rights which are the right of God and the universal human rights. The implication of this study is to give exposure to the community on the concept of euthanasia which is contrary to the concept of 'illness' as a test from God to man. The neglect of the major demands of the maqasid of sharia in particular to safeguard the lives of human beings will be neglected and human life will be exposed to elements of destruction and destitution. Therefore, research proposals on the role of maqasid of syariah in dealing with euthanasia issues are recommended.

\section{REFERENCES}

1. Abdul Halim, Muhammad Mansur ${ }^{\mathrm{c}}$ Ali. (2013). al-Qatlu bi Dafaci al-Syafaqah fi fiqh al-Islamiy wa al-Qanun al-Wadaci. $\mathrm{Jami}^{\mathrm{c}}$ ah al-Azhari wa Jamicah sl-Khalijiyah, Bahrain.

2. Manzoor, M. M. (2001). Euthanasia an: Islamic Perspective. Kuala Lumpur: IIUM. Press.

3. Michael North. (2002). Hippocratic Oath National Library olf Medicine. 
4. History of 2009. http://www.euthanasia.com/oathtext.html

Disember 2015]

5. Shuriye, A. O. (2011). Ethical and religious analysis on euthanasia. IIUM Engineering Journal, 12(5).

6. Robert, M. B., \& Stuart, E. R. (1989). Euthanasia: The Moral Issues, Contemporary Issues in Philosophy (Buffalo, N.Y: Prometheus Books, 9).

7. Mosby's Medical Dictionary. 2009. http://medicaldictionary.thefreedictionary.com/euthanasia [12May2016].

8. al-Qaradawi, Y. (2015). Fatwa Kontemporari, Jil. 2 (perubatan dan politik). Selangor: PTS. Islamika Sdn. Bhd.

9. Hirbah, S. (1986). Al-Qatl bi daafi' al-Rahmah. Majalah al-Qanun al-Muqarin, no:18. hlm.121.

10. Omur, E. (2001). Eubious Journal of Asian and International Bioethics 11. Eubious Ethics, Institute. 47-49.

11. Philip, G. (1996). The history place http://www.historyplace.com [ 28 Febuari 2015]

12. American Medical Association Council on Ethical and Judicial Affairs. (1992). Decisions near the End of Life. Journal of the American Medical Association. 267(16):2230.

13. Khairul, A. M. (2013). Hak Asasi Bukan Muslim di Malaysia: Analisis Isu terpilih. International Seminar on Islamic Jurisprudence in Contemporary Society. ISLAC.

14. Abdullah, O. N. (1987). Muhammed Encyclophedia of Seerah, vol. 5, London: Seerah Foundation.

15. Samuri, M. (2012). Penghakisan Nilai Agama Melalui Doktrin Hak Asasi. Panel Jawatankuasa Pemikir Isu Islam Semasa Pejabat Mufti Wilayah Persekutuan.

16. al-Attas, Syed Muhammad Naquib. (2001). Risalah Untuk Kaum Muslimin (ISTAC); hal.20.

17. Brian, P. (1998). Human Rights and Euthanasia (Anaesthetist and Palliative Care Physician).

18. Robert, P. (2004). Physician-Assisted Dying: The Case for Palliative Care and Patient Choice. University of Washington.

19. Justin, S. (2002). Belgian Docs Unhappy About Proposed Euthanasia Law. Reuters Health.

20. Otlowski. 2000. Voluntary Euthanasia and the Common Law. Oxford University Press.

21. John, K. (2002). Euthanasia Ethics and Public Policy and Argument Against Legislation. Cambridge University Press.

22. Bredan, G. (2005). Understanding Medical Law. Australia: Cavendish Publishing.

23. al-Sabuni. (1976). Safwatu al-Tafasir. Kaherah: Dar al-Sabuni. Jil 3.

24. al-Qurtubi. (1967). al-Jamic li Ahkam al-Qur'an. Kaherah: Dar Kitab al- ${ }^{\mathrm{C}}$ Arabi.
25. Tafsir Pimpinan Ar-Rahman. (2010). Cetakan ke21. Kuala Lumpur: Darul Fikr, dibawah kawalan JAKIM.

26. al-Asfahani. T.th. Muqaddimah fi al-Tafsir. Mesir: $\mathrm{Tab}^{\mathrm{c}}$ ah Jamaliyyah.

27. al-Harastai,I'sam Faris. (1994). Tafsir al-Tabari Min Kitabihi Jami' al-Bayan a'an Ta'wil A'yialQur'an. Jil.6 (surah al-Qasas- al-Jathiyyah). Beirut: Mua'sasah al-Risalah.

28. Al-Qur'an al-Karim.

29. al-Zuhaily, W. (2001). Tafsir al-Munir fi alAqidah wa al-Syaricah wa al-Manhaj. Persatuan Ulama Malaysia. Selangor: Intel Multimedia and Publication.

30. al-Bukhari. Sahih al-Bukhari. Kitab al-Mardha, Bab wada a al-yad ${ }^{c}$ ala al-Maridh.

31. Malik, M. M. (2012). Euthanasia: An Islamic Perspective.

32. al-Kafawi,Abu al-Baqa' Ayub, Muhammad alMisri. (1993). Al-Kuliyyat;Mu'jam al-Mustalahat wa Al-Furuq al-Lughawi.Muassasah al-Risalah. Cetakan kedua. Beirut: Lubnan.

33. Fairuzabadi, Muhammad Na'im. (1993). Qamus al-Muhit. Muassasah al-Risalah. Cetakan kedua. Beirut: Lubnan.

34. al-Zuhaily, Wahbah. (1989). Fiqh wa Adilatuhu. Jil.4. Damsyiq: Dar al-Fikr.

35. Ibn Nujaym, Zainuddin Ibrahim al-Hanafi. T.th. al-Bahr al-Rāiq Syarh Kanzu al-Daqāiq. Kaherah: Dar al-Kitab al-Islamiy li Ihya' wa Nasyar alTurath al-Islamiy.

36. ${ }^{\mathrm{c}}$ Abd al-Wahid Wafi, ${ }^{\mathrm{c}}$ Ali. T.th. al-Muwasah fi alIslam. Kaherah: Nahdah Misr.

37. al-Zuhaily, Wahbah. (2005). Usul al-Fiqh alIslami. Jil. 1. Damsyiq: Dar al-Fikr.

38. al-Mawdudi, S. Abul ${ }^{\mathrm{c}}$ Ala. (1986). Terjemahan Ramlee Ismail. Hak Asasi Manusia Dalam Islam. Kuala Lumpur: Dewan Bahasa dan Pustaka.

39. 'Audah, Abdul Qadir. (1986). Al-Tasyri' al-Jana'i al-Islami muqaranan bi al-Qanun al-Wada'i. Beirut:Mu'assah al-Risalah.

40. Abu Zahrah, Muhammad. T.th. al-Jarimah wa al${ }^{c}$ Uqubah fi al-Fiqh al-Islamiy. Kaherah: Dar alFikr al- ${ }^{\mathrm{C}}$ Arabi.

41. Al-Qaradawi, Y. (2001). Fi fiqh al-aqalliyyat almuslima. Cairo: Dar al-Shuruq.

42. Ibn Khaldun, Abu Zaid Abdul Rahman. (1995). Al-Muqaddimah. Kaherah: Dar Nahdah Masr.

43. al-Yubi Muhammad $\mathrm{Sa}^{\mathrm{c}} \mathrm{ad}$. (1998). Maqasid Syariah al-Islamiyyah wa Adillatuha al-Syar iyah. Riyadh: Dar al-Hijrah.

44. Ibn ${ }^{\mathrm{c}}$ Ashur, T. (2013). Maqasid al-Syari ${ }^{c} a{ }^{c}{ }^{c}$ inda Tahir bin ${ }^{c}$ Ashur. United Kingdom: Muassasah alFurqan lil Turath al-Islamiy.

45. al-Alusi. T.th. Ruh al-Ma'ani al-Qur'an al-A'zim wa al-Sab'I al-Mathani,jil 7, Beirut: Dar Ihya' alTurath al- ${ }^{\mathrm{c}}$ Arabi.

46. al-Asfahani. (1961). Mufradat fi Gharib alQur'an. Beirut: Dar-Ma ${ }^{c}$ rifah. 